\title{
Government IT related hi-tech company's incentives and subsidies role on industries in Hebei province, China
}

\author{
Faizo Kasule ${ }^{1 *}$, Li Zibiao ${ }^{2}$, Keyuan Sun ${ }^{3}$ \\ 1, 2,3 Department of Economics and Business Mnagement, Hebei University of Technology, Tianjin, China
}

\author{
Keywords \\ Government's incentives \\ Government's subsidies \\ Innovation performance \\ IT related Hi-Tech companies \\ Received: 18 June 2018 \\ Accepted: 20 July 2018 \\ Published: 2 August 2018
}

\begin{abstract}
Economic implications on government incentives to industries are key areas that require critical analysis in understanding the impacts. Tax incentives are the most predominant approach used in most cases in reducing various related costs. This paper aims to reveal the impact created by the government incentives on IT-related Hi-tech companies. This research uses the government annual survey data on Chinese listed corporations in Hebei province to investigate the incentives-related parameters. Data from a survey of 85 Information Technology (IT) related industries in Hebei province showed a significant positive impact of company's incentives role, the incentives given by the government increase output in industries. This study also examined the role that the government incentives played concerning high-tech related industries Using multiple regression analysis methods, the results indicated that related Hi-tech company's incentives created a significant impact in increasing the gross value of industrial output, impacting both product sales income and the commodity sales revenue. However, the results indicated that not all the government IT-related Hi-tech company's incentives led to improved total income between the study periods. Moreover, there would be an anticipated increase in employee rate if these incentives were constantly provided to Hi-tech companies consistently, but there was no clear increase in personnel over that period in totality. Therefore, this study provided room for discussion and further studies that would help in coming up with

other concrete evidence in subsequent years.
\end{abstract}

(C) 2018 The Author(s). Published by TAF Publishing.

\section{INTRODUCTION}

Tax incentives can be termed as any incentives that minimize the tax burden of enterprises so as to promote investment in a particular sector or projects. They are exceptions to the general tax brackets. Tax incentives offered by the government would include the following: tax holidays for the industries, reduced tax rates on acquired profits by the industries, accounting principles that smooth the way for depreciation and loss carry forwards for tax related function, and minimized tariffs on imported items such as; raw materials, tools and equipment, components or elevated market tariffs to guard the domestic market for import ad hoc investment projects.

Over the recent past, Governments have always promoted their countries as investment destinations to entice asso- ciated technology, limited private capital and managerial skills so as to improve in obtaining their development objectives. They have wholeheartedly adopted rules and regulations to support the advancement regarding the entry of Foreign Direct Investment (FDI), including promotional efforts plans which were adopted entails government provision of tax incentives, making the country regulations flexible and broad for the admission and establishment of foreign investment laws; promoting guarantees for profits and also recovery of investment; by laying down techniques for the settling of investment discourse in industries (Ahmad \& Mazlan, 2015; Shah, 2006; United Nations Conference on Trade and Development, 1999).

Tax incentives have become a predominant approach used by developed countries to lower various costs e.g., R\&D

* corresponding author: Faizo Kasule

†email: faizokasule1@yahoo.com 
costs, support enterprise by boosting R\&D input, and at the end, acquire Intellectual Property (IP). In this regard, the Government of China adopted a series of tax incentive for various industrial sectors. According to a survey conducted in 2010, the total credits for manufacturing industries by all levels of Chinese governments was 801.50 billion, which is $11.7 \%$ of internal $R \& D$ costs in manufacture (Hor, 2016; Ketsiri \& Pajongwong, 2016; Zhang, Jiang, \& Feng, 2017). Usually, the government applies tax incentives techniques to promote R\&D in Hi-tech industries. Taxation is one of the fundamental tools to push economic policies (Blanes \& Busom, 2004; Feng, Qu, \& Li, 2015; Yoo, Lee, \& Lee, 2016). Since tax incentives are designed to spur investment in selected sectors or geographic locations, they are not frequently provided without conditions. In most cases, countries formulate special incentive regimes that specify tax benefits in addition to the main restrictions. For example, these regimes may necessitate that a facility be set in a certain area, attain a certain set turnover, need for the transfer of technology from outside the country or create employment to a required number of individuals. As an example, as stated by the government of people's Republic of China, detailed rules and regulations for implementation of Foreign Enterprise Income Tax (FEIT) law (articles 69, $73,75,80,81$ and 82) and also the all-inclusive income tax law of for enterprises with foreign investment (Articles 7 to 10), China offers the foreign-invested firms a tax refund of roughly $40 \%$ on interests that is reinvested in the country so as to increase the capital for the industries or set up other new firms. The reinvestment duration of the profit attained is for at least five years otherwise, the company may be required to pay tax, that is, in case of withdrawal within five years. In case of foreign investors, if the reinvested amounts are withdrawn within a span of five years, the foreign investor must pay back the tax refunded. A 100\% tax refund is provided to foreign investors if profits are reinvested in an export-oriented enterprise within the country or an advanced enterprise which are technologically aligned i.es. Hitech industries.

Likewise, in India, tax exemption is offered on profits of firms engaged in tourism or travel, provided their earnings are received in exchangeable foreign currency. The cutbacks in the standard rates of corporate income tax and tax holidays are the most regularly used fiscal incentives across the globe, followed closely by import duties free, deductions from social security contributions et. cetera.

It was reported that, the merger of Republic of China's corporate income tax from the beginning of 2008 characterized a remarkable change. The aim of tax incentives changed to industry oriented rather than geographically oriented, aiming at projects promoted and backed by the country. The following are some of the incentives that demonstrate the Chinese government effort to promote technological advancements: (i) 15\% reduction of corporative income tax for new and high technology industries, (ii) for corporative tax purposes there was a super deduction of expenses related to research and development, (iii) income tax reduction or exemption from qualified technology transfer, (iv) diversifying tax holidays for both integrated circuit enterprises and software, (v) "Immediate levy, immediate refund" VAT policy for both the integrated circuit enterprises and software (Cai, Wong, \& Leung, 2011; Phyoe, 2015). In 2014, the ministry of finance in China effected the preferential tax rates, same as the rate that was given to 21 major cities in china, as part of a test programme to improve industry's competitiveness. This research unveils what lies behind the relationship between different tax incentives parameters provided by the Government of People's Republic of China during the period 2014-2016 and the influence of each variable on the growth of the selected Hi-tech industries within Hebei province, moreover, the research examines the government IT related Hi tech companies incentives role during 2014-2016 on improving the gross value of industrial products, impact of the various incentives on the commodity sales value, lastly it investigates the impact of tax incentives with respect to personnel employment rate, the findings of this study shed light on the interrelationship between gross value of industrial output, product sales, total income, personnel rate of employment and commodity sales revenue.

\section{LITERATURE REVIEW}

IT is a critical driving force in economic growth and development in China. Advanced development of science and technology in the 21st century, particularly information technology and life sciences, will lead to intellectual influence in political space, cultures and economic change around the world. In expert's viewpoint, digitization in the early years of the 21st century will give new momentum to development in information technology (Chou, C., Lin, \& Wu, 2017; McNally, 2007). Deng Xiaoping's arrangement in 1990 to open China's economy to foreign investment transformed the world's IT industries when China had an insignificant impact for world market for IT (Lewis, 2007). In October 29, 1997 in China, president Jiang Zemin affirmed his commitment to be part of the Information Technology Agreement (ITA) in a government-government meeting with the United States president Bill Clinton when he scraped off tariffs on semiconductors, computers, and other 
related IT products and during negotiations process. Jiang Zemin reaffirmed the measures in place for extra substantial reductions in tariff. A leading point in question that remains open both the accession to world trade organization relation to speed of tariff liberalization china committed in the negotiations and its engagement in the information technology agreement. China's IT Sector has now moved to focus of interest, inspiring, recognition, rivalry and suspicion.

Currently, China is dominating in the assembly of IT products and its leaders are enthusiastic to moving into more valuable activities. The last half a decade period plan detailed an aggressive aim in ensuring that China is an IT industrial hub and it matches that of Japan and US. China is number one manufacturer of semiconductors and it is in a process of building a globally competitive industry in software. China has become number one country for research and development in IT, industrial collaborating with other foreign companies.

The economy in the people's republic of China with respect to IT industries in the country, elimination of tariffs and other barriers to trade given that open market is a requirement for a competitive dynamics of IT industries. Tariffs plus other trade restrictions are inappropriate for the current competitive IT dynamics. Countries with policies encouraging "national champions" behind secured national border line will experience slower growth of information technology activities, concurrently their domestic IT firms will be technological slower compared to open market competitive IT industries (Borrus \& Cohen, 1997). Moreover, the primary focus attention on other areas like market profile and product constraints of China IT Services, performance of China IT industry, catalytic product's role of IT Industry in China economy, analysis of China's International Trends in IT Products, strategy for development of IT dynamics in the country, opportunity for boosting FDI and ITA for IT Sector. Finally, with a view to strengthen the analytical framework for studies in IT sector's contribution in China economy, it is advantageous to intensify the research efforts in above-selected aspects.

Chinese law creates a platform for doing business by providing tax incentives and tax breaks for information technology companies incorporated making China a tax haven for business operations. The new law of taxation of corporate income which is the corporate income tax law applied and its implementing decree that entered into force in January 1st 2008, creates the chances for firms that have been assigned the title "High-Tech companies" which comprises of but not limited to the following field of tasks, electron information and transformation of local traditional firms through application of new technologies to take advantage of a preferential tax rate of $15 \%$ plus $50 \%$ deductions meant for research related studies and development expenses compared to a common law which is currently standard $25 \%$ corporate income tax rate. The following are incentives provided by Chinese government that reflect its effort to boost technological developments: reduced corporate income tax rate of $15 \%$ for new and High Tech ventures, different corporate income tax breaks for software and. On tax exemption and reduction as per the Article 27(4) and Article 90 of Detailed Implementation Rules, the first 5,000,000 Yuan of related income obtained from tax resident enterprises from technological transfer shall be exempted from CIT and the proportion exceeding 5,000,000 RMB shall be subjected to half the total amount reduction. China provides an exigent case antiquity that several low- and middle-income countries always try to emulate. The Chinese government, both local and central have depended to a greater extent on industrial policy to spur indigenous innovation and technological enhancement, and enhance regional growth and catch-up IT policies including; financed raw materials, low cost loans, tax incentives, reduced energy cost, public subsidies, and provision of land, are being used to assist in reorganizing the economy and remodel China into an innovation-oriented society. Public subsidies are an indispensable element of China's industrial policy and are assigned crosswise diverse industries in China (Howell, 2017). A subsidy is hinged on the Export Share Requirement (ESR) when companies have to export more than a set amount of share of their return on obtaining it. Aforementioned incentives are irregularly found in EPZs and Free Trade Zones (FTZs), these measures targets foreign investors, both in China and other parts of the world specifically developing countries (Defever \& Riaño, 2017). Hi-tech sector incomparably contributes to the GDP of China. The portion of value added of Hi-tech industry to the value added of manufacturing has been increasing from 0.095 in 2001 to 0.127 in 2007. Assisting Hi-tech's innovation and development of science and technology are critical goals for both the local and national government of China. The increasing R\&D spending, development of science \&technology institutes and developing technical staff would make Hi-tech industries of China competitive locally in the same way, internationally, appeals to majority of FDI in this industry (Qazi \& Yulin, 2012). 


\section{METHODOLOGY}

The authors conducted a systematic review of the existing relevant academic publications. The systematic review is a technique to address a specific question or problem by recapitulating the existing literatures and presenting it in one single document. To identify the major tax incentive implications, the study relied on the documents related to China and also conducted an extensive online search of Hi tech industries in China in addition to the data from a survey of 85 IT related industries in Hebei province and analysis conducted using multiple regression analysis method.

The rest of this research paper is systematically arranged as follows. Section III deals with the literature review, section IV discusses China's tax incentives and subsidies in China, section $\mathrm{V}$ describes the data, hypotheses and the analysis, section VI provides the research concluding remarks. Then the principal conclusion is drawn in section $\mathrm{V}$ and section VI.

The study makes two contributions to the literature. First, we conceptualize incentives and subsidies role on economic and technological performances. Secondly, the panel data was analyzed using descriptive statistics, correlation analysis and panel regression analysis. The panel methodology was supported by STATA software.

\section{CHINA TAX INCENTIVES AND SUBSIDIES}

Taxes contribute crucial revenue source for the government of China, tax is a major constituent of microeconomic policy and hugely affects China social and economic development, with main changes effected in 1994 tax reform, the People's Republic of China has initially put in place a streamlined tax system geared towards socialist market economy, with a series of adjustment and improvement of the tax system which contributed to fast economic country growth, there are eighteen types of taxes in china (Abou, 2000).

Special incentives were admitted for investment in the following provinces in China, Shenzhen, Zhuhai in Guangdong and Shantou; the special economic zones were in Fujian province. The rate of income tax was 15\% imposed on production-oriented Foreign Investment Enterprises (FIEs) in special economic zones.

Similarly, China also offered a reduced rate for FIEs in Economic and Technological Development Zones (ETDZs), this was predominantly on the China's coastal cities such as; Tianjin, Shanghai, Yantai, Beihai, Dalian, Zhanjiang, Qinhuangdao, Fuzhou, Guangzhou, Lianyungang, Nantong, Qinhuangdao, Ningbo, Qingdao, Qinhuangdao, and Beijing. Various locations also effect the successful models of the ETDZs and SEZs (United Nations Conference on Trade and Development, 1999).

ISSN: $2414-309 \mathrm{X}$

DOI: $10.20474 /$ jabs-4.4.4
It was observed that public subsidies have also been associated precisely to the economic performance of firms in China for instance, they realized that a specific amount of subsidies create impact on firms' productivity, at the same time receiving relatively more subsidies may create a negative effect. The main shortcomings with the existing literatures is that they mostly focus on the subsidies effects on a single stage of innovation without examining how subsidies may influence the industrial performance of the hitech firms economically. Notwithstanding, a great percentage of the new product, commodities or process sales entails revenue streams that originate from the adoption of external/latest technology developed by other industries in different locations (Howell, 2017; Lu \& Tao, 2009). A large portion of these allocations will be the adoption of new processes instead of products. As in other transitioning and developing economies, the new innovation sales intermediary includes a broader perception of innovation, including adaptive and cumulative methods of innovation that include revenue streams that stem from the adoption of external technology, primarily processes, and developed by other firms in different regions. It was illustrated in his detailed survey of literature that labor productivity, total factor productivity, and profitability are the three performance indicators used most often to measure and compare the performance of Chinese enterprises under various ownership classifications (Jefferson \& Singh, 1999). State subsidies are extensive among Chinese listed firms (Allen, Qian, \& Qian, 2005; Lee, Walker, \& Zeng, 2014). Existing studies provided evidence that state subsidies generate a material impact on the market value and the financial reporting of Chinese firms. Despite of this, the concerns about state subsidies has not been investigated by preceding studies as a purpose of corporate social responsibility disclosures in China (S. Chen \& Wang, 2004; X. Chen, Lee, \& Li, 2008; Marquis \& Qian, 2013).

\section{HYPOTHESES, DATA DESCRIPTION, ANALYSIS AND RE- SULTS}

The study hypotheses were:

I. The government IT related Hi-tech company's incentives play a role of increasing the gross value of industrial output between the years 2014-2016.

II. The government incentives created an impact in both the product sales income and the commodity sales revenue.

III. The government IT related Hi-tech company's incentives led to improved total income between the years 2014-2016. IV. The engineering and technical personnel employment rate increased and the average annual number of employees increased. 
TABLE 1. Government IT related Hi-Tech subsidies

\begin{tabular}{|c|c|c|c|c|c|c|c|c|c|c|}
\hline Year & $\begin{array}{l}\text { Subsidy } \\
\text { Income }\end{array}$ & $\begin{array}{l}\text { \% sub- } \\
\text { sidy } \\
\text { Income }\end{array}$ & $\begin{array}{l}\text { Total } \\
\text { Tax } \\
\text { Relief }\end{array}$ & $\begin{array}{ll}\% & \text { To- } \\
\text { tal } & \text { Tax } \\
\text { Relief }\end{array}$ & $\begin{array}{l}\text { VAT } \\
\text { Relief }\end{array}$ & $\begin{array}{l}\text { \% VAT } \\
\text { Relief }\end{array}$ & $\begin{array}{l}\text { Income } \\
\text { relief }\end{array}$ & $\begin{array}{l}\% \text { In- } \\
\text { come } \\
\text { relief }\end{array}$ & $\begin{array}{l}\text { Enjoy Hi-tech en- } \\
\text { terprise income } \\
\text { tax relief }\end{array}$ & $\begin{array}{l}\text { \% Enjoy Hi- } \\
\text { tech enterprise } \\
\text { income tax relief }\end{array}$ \\
\hline 2014 & 76035.2 & 29.1 & 110214 & 22.89 & 23936.8 & 26.26 & 84947 & 22.06 & 68757 & 23.6672 \\
\hline 2015 & 89493.4 & 34.2 & 175051 & 36.36 & 34255.7 & 37.59 & 139128 & 36.14 & 105119 & 36.1832 \\
\hline 2016 & 95559.3 & 36.6 & 196124 & 40.74 & 32946.6 & 36.15 & 160933 & 41.79 & 116642 & 40.1496 \\
\hline Total & 261088 & & 481390 & & 91139 & & 385009 & & 290520 & \\
\hline
\end{tabular}

* Values in thousand

Role of Government IT Related Hi-tech Company's Subsidies on Increasing the Gross Value of Industrial Output between the Years 2014-2016

This section will address objective one of the study that reads: the government IT related hi tech company's subsidies plays a role of increasing the gross value of industrial output between the years 2014-2016. From Table 1, taking into account years 2014, 2015 and 2016 in comparison with the gross value of industrial output within this period, the results showed that the output was on its highest (35.80\%) in the year 2015 when the companies' received higher share of total income relief and VAT relief (Table 2). This gives an indication perhaps that government IT related hi-tech company's subsidies impacts negatively on gross value industrial output. It further indicates the higher likelihood of VAT relief to have more positive impact as compared to the rest of subsidies offered. This is further portrayed in Figure 1 where in the said years the higher the subsidy the higher the gross value industrial output. This was regardless of the subsidy type, where in the said years the higher the subsidy the higher the gross value industrial output.

TABLE 2. Gross value of industrial output between years 2014-2016

\begin{tabular}{lll}
\hline \hline Year & The gross value of industrial output & \% Total of the gross value of industrial output \\
\hline 2014 & 12810664 & 34.29446922 \\
2015 & 13376374 & 35.80888871 \\
2016 & 11167860 & 29.89664207 \\
Grand Total & 37354899 & 100 \\
\hline
\end{tabular}

TABLE 3. Subsidies and gross value of industrial product by year

\begin{tabular}{lllll}
\hline \hline Year & The gross value of industrial output & The subsidy income & The total tax relief & VAT relief \\
\hline 2014 & 12810664 & 76035.22 & 110214.4 & 23936.77 \\
2015 & 13376374 & 89493.39 & 175051.4 & 34255.66 \\
2016 & 11167860 & 95559.39 & 196123.9 & 32946.58 \\
Total & 37354899 & 261088 & 481389.6 & 91139.01 \\
\hline \hline
\end{tabular}

*Values in thousand

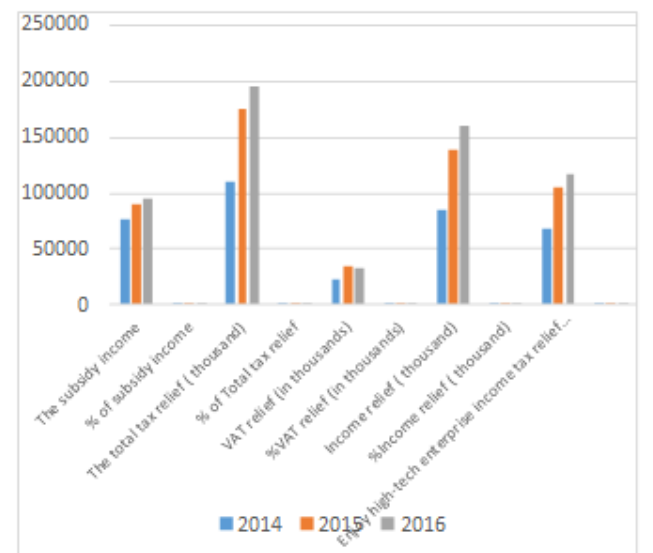

FIGURE 1. Relation between government hi-tech subsidies to gross value of industrial output 
When a regression was conducted, the results revealed a high degree of correlation between government hi-tech subsidies with gross value of industrial output $\left(R^{2}=\right.$ 0.928). The ANOVA test indicated that the regression model predicted the dependent variable significantly well $(F=$ 5.04665, $p=0.001$ ). The subsidy income, total tax relief and VAT relief were all significantly associated with gross value of industrial product $(p<0.05)$. Despite enjoy hi- tech enterprise relief not significantly it affected positively on gross value of industrial product same as total tax relief by (31.127 and 157.070 increase of units, respectively. However, VAT and income relief showed a negative effect by -188.586 and -116.292-unit decrease on gross value of industrial products, respectively (Table 2 , Table 3 , Table 4 and Table 5).

TABLE 4. Regression analysis: Dependent variable gross value of industrial product

\begin{tabular}{|c|c|c|c|c|c|c|c|}
\hline \multirow[t]{2}{*}{ Model } & \multicolumn{2}{|c|}{$\begin{array}{c}\text { Unstandardized } \\
\text { Coefficients } \\
\end{array}$} & \multirow{2}{*}{$\begin{array}{l}\text { Standard- } \\
\text { ized } \\
\text { Coefficients } \\
\text { Beta }\end{array}$} & \multirow[t]{2}{*}{$t$} & \multirow[t]{2}{*}{ Sig. } & \multicolumn{2}{|c|}{$\begin{array}{c}\text { 95.0\% Confidence } \\
\text { Interval for B }\end{array}$} \\
\hline & B & $\begin{array}{l}\text { Std. } \\
\text { Error }\end{array}$ & & & & $\begin{array}{l}\text { Lower } \\
\text { Bound }\end{array}$ & $\begin{array}{l}\text { Upper } \\
\text { Bound }\end{array}$ \\
\hline (Constant) & 42572.050 & 53797.52 & & .791 & .431 & -64488.445 & 149632.545 \\
\hline The subsidy income & 67.003 & 27.677 & .280 & 2.421 & .018 & 11.925 & 122.082 \\
\hline VAT relief & -188.586 & 109.272 & -.407 & -1.726 & .088 & -406.044 & 28.872 \\
\hline The total tax relief & 150.684 & 92.966 & .901 & 1.621 & .109 & -34.324 & 335.693 \\
\hline $\begin{array}{l}\text { Enjoy high-tech enterprise } \\
\text { income tax relief }\end{array}$ & -116.292 & 97.746 & -.537 & -1.190 & .238 & -310.813 & 78.228 \\
\hline
\end{tabular}

* Vaules in thousand

TABLE 5. ANOVA ${ }^{\mathrm{b}}$

\begin{tabular}{llllll}
\hline \hline Model & Sum of Squares & $\boldsymbol{d} \boldsymbol{f}$ & Mean Square & $\boldsymbol{F}$ & Sig. \\
\hline Regression & $3.712 \mathrm{E} 12$ & 4 & $9.279 \mathrm{E} 11$ & 5.046 & $.001 \mathrm{a}$ \\
Residual & $1.471 \mathrm{E} 13$ & 80 & $1.839 \mathrm{E} 11$ & & \\
Total & $1.842 \mathrm{E} 13$ & 84 & & & \\
\hline \hline
\end{tabular}

a. Predictors: (Constant), Enjoy high-tech enterprise income tax relief (in thousands), The subsidy income, VAT relief (in thousands), The total tax relief ( thousand)

b. Dependent Variable: The gross value of industrial output

In regard to hypothesis one of the study, the findings showed that between 2014-2016, the gross value of industrial product increased as a result of subsidies. However, in 2016 when the subsidies income increased, there was a reduction in gross value of industrial product. The great effect of government related subsidies issued to hi-tech firms in Hebei province was in 2015. However, the overall grand total of subsidy between 2014-2016 reduced the gross value of industrial product. Therefore, the conclusion reached is that the government IT related hi tech firm's subsidies creates an effect of improving the gross value of industrial output between 2014-2016. However, not all subsidies have a positive influence, and some would have negative effect on gross value of industrial output.

\section{Government Subsidies in Relation to Product Sales In- come}

When product sales income was subjected for further analysis in relation to government subsidies, the total relief income tax, income relief and VAT relief were significant except High-tech enterprise relief. This an indication that government subsidies created an impact in product sales income, the distribution function is presented in Figure 2. In regard to hypothesis two of the study on whether the government incentives created an impact in both the product sales income and the commodity sales revenue, the finding further showed that the year when hi-tech related company's registered highest sales revenue and commodity sales revenue is the year that the companies received highest tax and VAT relief likewise when the companies received highest subsidy income in the year 2016, they did register highest commodity sales revenue. 


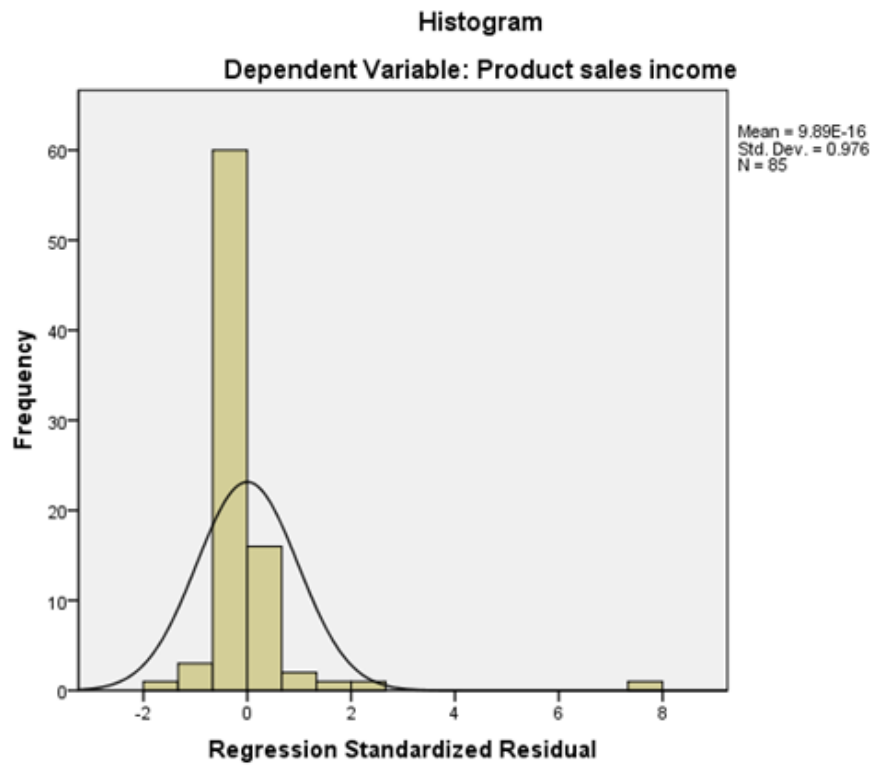

FIGURE 2. Distribution function of product sales income

The fact that at one point the hi-tech industries registered significant product sales income and commodity sales revenue and the results showed that these positive impact were attributed to certain subsidies more especially to tax and VAT relief. On further analysis, the findings showed that government high-tech related subsidies had an impact on product sales income except commodity sales revenue. The conclusion therefore reached is government subsidies created an impact in the product sales income.

TABLE 6. Regression on government subsidies in relation to product sales income

\begin{tabular}{|c|c|c|c|c|c|c|c|}
\hline \multirow[t]{4}{*}{ Coefficients $^{\mathrm{a}}$ Model } & \multirow{2}{*}{\multicolumn{2}{|c|}{$\begin{array}{c}\text { Unstandardized } \\
\text { Coefficients } \\
\end{array}$}} & \multirow{4}{*}{$\begin{array}{l}\text { Standard- } \\
\text { ized } \\
\text { Coefficients } \\
\text { Beta }\end{array}$} & \multirow[t]{4}{*}{$t$} & \multirow[t]{4}{*}{ Sig. } & \multirow{2}{*}{\multicolumn{2}{|c|}{$\begin{array}{c}\mathbf{9 5 . 0 \%} \text { Confidence } \\
\text { Interval for B } \\
\end{array}$}} \\
\hline & & & & & & & \\
\hline & \multirow[t]{2}{*}{ B } & Std. & & & & Lower & Upper \\
\hline & & \multirow{2}{*}{\multicolumn{2}{|c|}{$\begin{array}{l}\text { Error } \\
53960.1\end{array}$}} & & & Bound & Bound \\
\hline (Constant) & 34274.3 & & & .6 & .527 & -73109.7 & 141658 \\
\hline The subsidy income & 83.4 & 27.7 & .344 & 3.0 & .004 & 28.2 & 138 \\
\hline VAT relief (in thousands) & -169.9 & 109.6 & -.362 & -1.55 & .125 & -388.1 & 48 \\
\hline $\begin{array}{l}\text { Enjoy high-tech enterprise } \\
\text { income tax relief (in thou- } \\
\text { sands) }\end{array}$ & -90.8 & 98.0 & -.414 & -.9 & .357 & -285.9 & 104 \\
\hline $\begin{array}{l}\text { The total tax relief ( thou- } \\
\text { sand) }\end{array}$ & 121.381 & 93.2 & .7 & 1.3 & .197 & -64.1 & 306 \\
\hline
\end{tabular}

TABLE 7. Regression on government subsidies in relation to commodity sales

\begin{tabular}{llllll}
\multicolumn{2}{c}{ revenue } & \multicolumn{1}{c}{} \\
\hline \hline ANOVA $^{\text {b }}$ Model & Sum of Squares & $\boldsymbol{D} \boldsymbol{f}$ & Mean Square & $\boldsymbol{F}$ & Sig. \\
\hline Regression & 6399698.132 & 4 & 1599924.533 & .136 & $.969^{\mathrm{a}}$ \\
Residual & $9.432 \mathrm{E} 8$ & 80 & $1.179 \mathrm{E} 7$ & & \\
Total & $9.496 \mathrm{E} 8$ & 84 & & & \\
\hline \hline
\end{tabular}

a. Predictors: (Constant), Enjoy hi tech enterprise income tax relief (in thousands), VAT relief (in thousands), income relief (in thousands, the total tax relief (thousands).

b. Dependable variable; commodity sales value 
TABLE 8. Coefficients ${ }^{a}$

\begin{tabular}{|c|c|c|c|c|c|c|c|}
\hline \multirow[t]{4}{*}{ Model } & \multicolumn{2}{|c|}{ Unstandardized } & \multirow{4}{*}{$\begin{array}{l}\text { Standard- } \\
\text { ized } \\
\text { Coefficients } \\
\text { Beta }\end{array}$} & \multirow[t]{4}{*}{$t$} & \multirow[t]{4}{*}{ Sig. } & \multicolumn{2}{|c|}{ 95.0\% Confidence } \\
\hline & \multicolumn{2}{|c|}{ Coefficients } & & & & \multicolumn{2}{|c|}{ Interval for B } \\
\hline & $\mathbf{B}$ & Std. & & & & Lower & Upper \\
\hline & & Error & & & & Bound & Bound \\
\hline (Constant) & 1082.4 & 413.515 & & 2.6 & .011 & 259.700 & 1905 \\
\hline VAT relief (in thousands) & .229 & .806 & .069 & .284 & .777 & -1.375 & 1.833 \\
\hline $\begin{array}{l}\text { Enjoy high-tech enterprise } \\
\text { income tax relief (in thou- } \\
\text { sands) }\end{array}$ & .191 & .698 & .123 & .274 & .785 & -1.198 & 1.580 \\
\hline $\begin{array}{l}\text { The total tax relief ( thou- } \\
\text { sand) }\end{array}$ & -.272 & .651 & -.226 & -.4 & .677 & -1.568 & 1.024 \\
\hline
\end{tabular}

Dependent Variable: Commodity sales revenue

\section{Whether the Government Subsidies Created an Impact on Commodity Sales Revenue}

Unlike to product sales income and commodity sales value of the industry none of the government related subsidies was significant in comparison to commodity sales revenue. This is an impression that the latter had no impact on the former over the period. Government IT related hi Tech Company's subsidies impact on total income between years -2014-2016.

This section presents hypothesis three of the study which is the government IT related Hi-tech company's subsidies lead to improved total income between years 2014-2016. Table 7 illustrates total income for the hi-tech related firms between 2014-2016. The findings show that the company's registered the highest total income in 2015 account- ing $35.51 \%$ of $40,705,509.54$ total incomes that was registered. The results confirmed that total income was impacted to an extent by the government subsidies on hi-tech companies. However, the impact was more pronounced as a result of VAT relief in the year 2015. On further examination, when the variables were subjected to regression, the findings revealed that the impact was either positive or negative in regard to type of government subsidies. The VAT relief would positively contribute to increase of total income as compared to the rest (Total tax relief, Income relief and enjoy hi tech enterprise relief). Hence, the study concluded that not all the government IT related Hi-tech company's subsidies that led to improved total income between years 2014-2016.

TABLE 9. Total income between years 2014 to 2016

\begin{tabular}{ccc}
\hline \hline Year & Total Income & \% of the Total Income \\
\hline 2014 & 13390854.03 & 32.89690801 \\
2015 & 14451506.64 & 35.50258135 \\
2016 & 12863148.87 & 31.60051063 \\
Total & 40705509.54 & \\
\hline \hline
\end{tabular}

TABLE 10. Regression analysis

\begin{tabular}{llllll}
\hline \hline ANOVA $^{\mathbf{b}}$ Model & Sum of Squares & $\boldsymbol{D} \boldsymbol{f}$ & Mean Square & $\boldsymbol{F}$ & Sig. \\
\hline 1 Regression & $1.500 \mathrm{E} 13$ & 4 & $3.749 \mathrm{E} 12$ & 65.423 & $.000^{\mathrm{a}}$ \\
Residual & $4.584 \mathrm{E} 12$ & 80 & $5.731 \mathrm{E} 10$ & & \\
Total & $1.958 \mathrm{E} 13$ & 84 & & & \\
\hline \hline
\end{tabular}

a. Predictors: (Constant), Enjoy high-tech enterprise income tax relief (in thousands), VAT relief (in thousands), Income relief ( thousand), The total tax relief ( thousand)

b. Dependent Variable: The total income 
TABLE 11. Coefficients ${ }^{\mathrm{a}}$

\begin{tabular}{|c|c|c|c|c|c|c|c|}
\hline \multirow[t]{4}{*}{ Model } & \multirow{2}{*}{\multicolumn{2}{|c|}{$\begin{array}{c}\text { Unstandardized } \\
\text { Coefficients }\end{array}$}} & \multirow{4}{*}{$\begin{array}{l}\text { Standard- } \\
\text { ized } \\
\text { Coefficients } \\
\text { Beta }\end{array}$} & \multirow[t]{4}{*}{$t$} & \multirow[t]{4}{*}{ Sig. } & \multicolumn{2}{|c|}{ 95.0\% Confidence } \\
\hline & & & & & & \multicolumn{2}{|c|}{ Interval for $B$} \\
\hline & B & Std. & & & & Lower & Upper \\
\hline & & Error & & & & Bound & Bound \\
\hline 1 (Constant) & 69674.397 & 29031.07 & & 2.400 & .019 & 11900.709 & 127448.085 \\
\hline VAT relief (in thousands) & -3239.524 & 207.546 & -6.784 & -15.609 & .000 & -3652.554 & -2826.494 \\
\hline $\begin{array}{l}\text { Enjoy high-tech enterprise } \\
\text { income tax relief (in thou- } \\
\text { sands) }\end{array}$ & 13.815 & 51.379 & .062 & .269 & .789 & -88.433 & 116.062 \\
\hline $\begin{array}{l}\text { The total tax relief (thou- } \\
\text { sand) }\end{array}$ & 3230.223 & 206.897 & 18.741 & 15.613 & .000 & 2818.486 & 3641.961 \\
\hline Income relief (thousand) & -3201.440 & 216.925 & -15.450 & -14.758 & .000 & -3633.135 & -2769.745 \\
\hline
\end{tabular}

a. Predictors: (Constant), Enjoy high-tech enterprise income tax relief (in thousands), VAT relief (in thousands), Income relief ( thousand), The total tax relief ( thousand)

b. Dependent Variable: The total income

\section{Regression Analysis: Government Subsidies in Relation to Total Income}

When a regression was conducted, the results revealed a high degree of correlation between government Hi-tech subsidies and total income $\left(R^{2}=0.979\right)$. The ANOVA test demonstrated that the regression model predicted the dependent variable considerably well $(F=65.423, p=0.000)$. The total tax relief, income relief and VAT relief were all significantly associated with total income of industrial product $(p<0.05)$. Only Enjoy high-tech enterprise income tax relief was not significant. However, the tax relief positively relates to total income while the rest had a negative effect. The equation therefore arrived was Total income $=$ 69674.397-3239.524 VAT Relief + 13.815 Enjoy high-tech enterprise income tax relief (in thousands) +3230.223 total tax relief-3201. Income relief (thousand). This therefore falls below the total income realized at the period an indica- tion that not all government subsidies that have a positive impact towards the total income of Hi-tech companies.

\section{Employment Rate between Years 2014-2016}

This section presents the fourth hypothesis of the study. The hypothesis was engineering and technical personnel employment rate increased and the average annual number of employees increased. The results showed that the actual active annual average number of employees recorded was high in the year 2016, 2015 and then 2014 by $34.24 \%$, $33.14 \%$ and $32.63 \%$, respectively. In the year 2015 , the companies registered high (36.75\%) of engineering and technical employees (Table 8) and Figure 3. This is the year too from the previous results indicated having great impact due to government subsidies that were provided during the year, the regression analysis is as shown in Table 9 and the distribution function are as illustrated in Figure 4.

TABLE 12. Variation of engineering and technical personnel and the average number of employees

\begin{tabular}{lllll}
\hline \hline Year & $\begin{array}{l}\text { Engineering and techni- } \\
\text { cal personnel (person) }\end{array}$ & & $\begin{array}{l}\text { The annual average } \\
\text { number of employees } \\
\text { (person) }\end{array}$ & \\
\hline 2014 & 6239 & 32.09 & 18929 & 32.63 \\
2015 & 7144 & 36.75 & 19225 & 33.14 \\
2016 & 6057 & 31.16 & 19865 & 34.24 \\
Total & & 58019 & \\
\hline \hline
\end{tabular}


TABLE 13. Variation of engineering and technical personnel and the average number of employees

\begin{tabular}{|c|c|c|c|c|c|c|c|}
\hline \multicolumn{8}{|l|}{ Coefficients $^{\mathrm{a}}$} \\
\hline \multirow[t]{4}{*}{ Model } & \multicolumn{2}{|c|}{ Unstandardized } & \multirow{4}{*}{$\begin{array}{l}\text { Standard- } \\
\text { ized } \\
\text { Coefficients } \\
\text { Beta }\end{array}$} & \multirow[t]{4}{*}{$t$} & \multirow[t]{4}{*}{ Sig. } & \multicolumn{2}{|c|}{ 95.0\% Confidence } \\
\hline & \multicolumn{2}{|c|}{ Coefficients } & & & & \multicolumn{2}{|c|}{ Interval for B } \\
\hline & B & Std. & & & & Lower & Upper \\
\hline & & Error & & & & Bound & Bound \\
\hline 1 (Constant) & 38.468 & 9.745 & & 3.947 & .000 & 19.085 & 57.852 \\
\hline $\begin{array}{l}\text { The annual average num- } \\
\text { ber of employees (person) }\end{array}$ & .157 & .021 & .625 & 7.299 & .000 & .114 & .200 \\
\hline
\end{tabular}

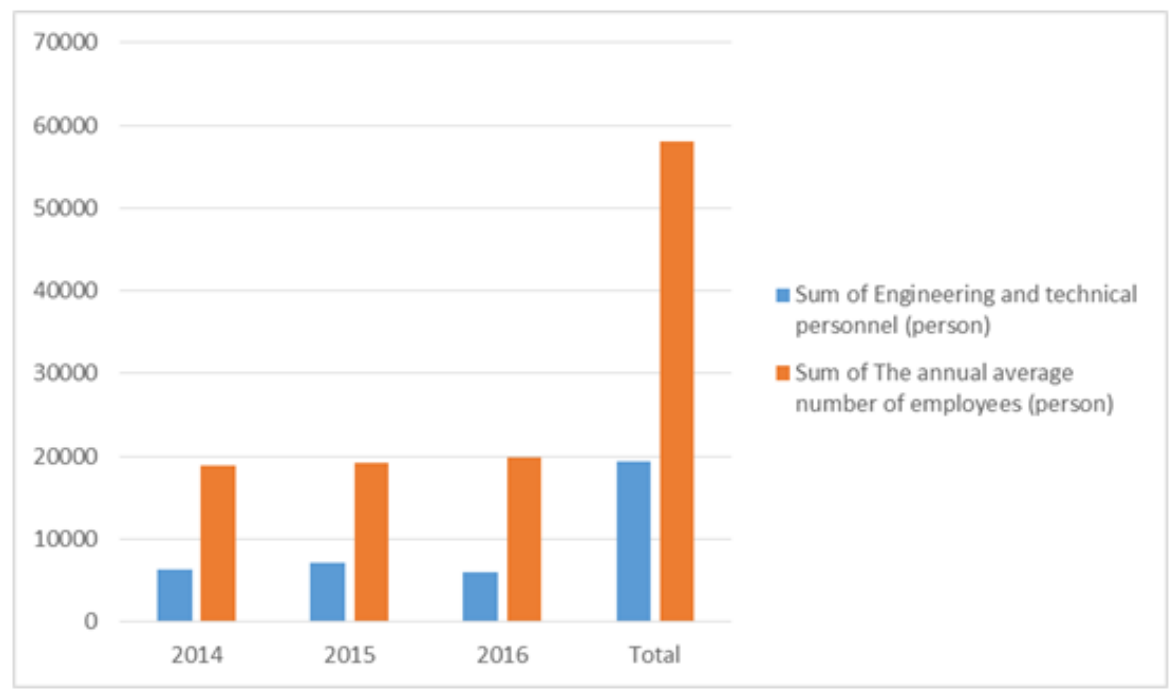

FIGURE 3. Yearly variation of personnel

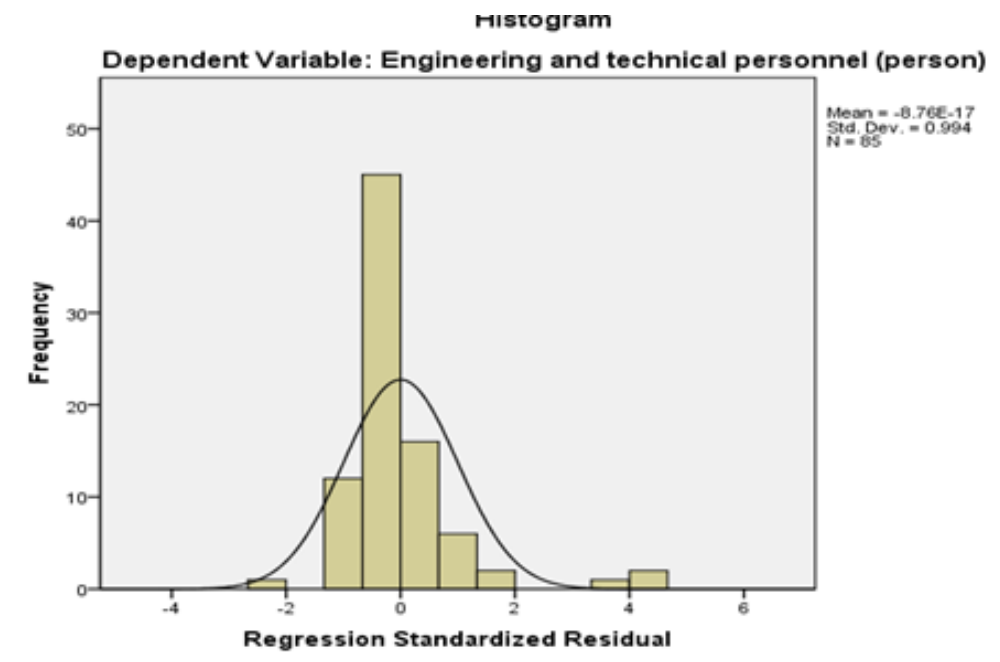

FIGURE 4. Distribution function of the total income

In regard to fourth hypothesis of the study on whether engineering and technical personnel employment rate increased and the average annual number of employees increased due to various incentives given by the government and the related subsidies, the data indicates that the annual average number of employees was high in 2016 when the subsidies allocated to the hi-tech industries increased, however, there was no correlation between the annual number of employees and the sum of engineering and technical personnel, furthermore, regression analysis showed no significant effect between engineering and technical personnel employment rate increased and the average annual number 
of employees. The findings revealed there was no consistence in the increase of average annual personnel over the years. There was fluctuation over the period hence no clear roadmap to show the increase rate. Therefore, there was no increase in terms of personnel and also in terms of engineering and technical employees over the years. However, in the year 2016 when high government subsidies on tax and VAT relief was registered, there was a sharp increase number of annual personnel.

\section{CONCLUSION \& IMPLICATIONS}

The study realized that the gross value of industrial product increased as a result of subsidies hence it can be deduced that the government IT related Hi tech firm's subsidies creates an effect of improving the gross value of industrial output between 2014-2016. The findings further revealed there was no consistence in the increase of average annual personnel over the years. There was fluctuation over the period hence no clear roadmap to show the increase rate. Therefore, there was no increase in terms of personnel and also in terms of engineering and technical employees over the years. However, in the year 2016 when high government subsidies on tax and VAT relief was registered, there was a sharp increase number of annual personnel. An indication that there would be anticipated increase employee rate if these subsidies were constantly provided to hi-tech companies consistently. The conclusion therefore reached was that there was no increase in average annual number of employees due to engineering and technical personnel employment rate increase, lastly, some other factors may have also contributed to the above improvements during this period of study, such as capital investment, enterprise age, enterprise scale, and human resource investment. This research therefore is significant in creating a fundamental platform for other researcher's analyzing the impact of incentives and subsidies in subsequent years. The main limitation of this research is difficulty in obtaining government related data, hence we were unable to obtain the most recently updated data. The research aims to enhance the standardization management of high-tech enterprises of China based on the economic support.

\section{ACKNOWLEDGEMENT}

I sincerely thank my Professor Li Zibiao for his brilliant guidance, my fellow student George Adwek for his continuous support and contribution. This research was done at Hebei University Department of Business and Management.

\section{REFERENCES}

Abou, N. W. (2000). Tax incentives and foreign direct investment. Retrieved from https://bit.ly/2SUNSAJ (accessed on 13 June, 2017)

Ahmad, N., \& Mazlan, N. F. (2015). Banking fragility sector index and determinants: A comparison between local-based and foreign-based commercial banks in Malaysia. International Journal of Business and Administrative Studies, 1(1), 5-17. doi:https://doi.org/10.20469/ijbas.10002

Allen, F., Qian, J., \& Qian, M. (2005). Law, finance, and economic growth in China. Journal of Financial Economics, 77(1), 57-116. doi:https://doi.org/10.1016/j.jfineco.2004.06.010

Blanes, J. V., \& Busom, I. (2004). Who participates in r\&d subsidy programs? The case of Spanish manufacturing firms. Research Policy, 33(10), 1459-1476. doi:https://doi.org/10.1016/j.respol.2004.07.006

Borrus, M., \& Cohen, S. (1997). Building China's information technology industry: Tariff policy and China's accession to the WTO. In Third Meeting of the Trilateral Forum, Berkeley, CA.

Cai, A., Wong, S., \& Leung, C. (2011). Tax incentives for high technology industries in China, China tax. Retrieved from https://bit.1y/1lmf1It (accessed on 14 June, 2017)

Chen, S., \& Wang, Y. (2004). Evidence from China on the value relevance of operating income vs. below-the-line items. The International Journal of Accounting, 39(4), 339-364. doi:https://doi.org/10.1016/j.intacc.2004.06.012

Chen, X., Lee, C.-W. J., \& Li, J. (2008). Government assisted earnings management in China. Journal of Accounting and Public Policy, 27(3), 262-274. doi:https://doi.org/10.1016/j.jaccpubpol.2008.02.005

Chou, Y. C., C., C. T., Lin, S. Y., \& Wu, S. Y. (2017). A development strategy for the leisure industry in Taiwan. International Journal of Business and Economic Affairs, 2(1), 12-17. doi:https://doi.org/10.24088/ijbea-2017-21003

Defever, F., \& Riaño, A. (2017). Subsidies with export share requirements in China. Journal of Development Economics, 126, 33-51. doi:https://doi.org/10.1016/j.jdeveco.2016.12.003

Feng, H., Qu, W., \& Li, M. (2015). Does tax incentives induce R\&D investment in firms? Studies in Science of Science, 5, 665-673. 
Hor, C. (2016). Analysis of the impact of determinant factors on foreign direct investment in Cambodia: The ARDL bounds testing approach. Journal of Administrative and Business Studies, 2(4), 177-188. doi:https://doi.org/10.20474/jabs-2 .4 .4

Howell, A. (2017). Picking 'winners' in China: Do subsidies matter for indigenous innovation and firm productivity? China Economic Review, 44, 154-165. doi:https://doi.org/10.1016/j.chieco.2017.04.005

Jefferson, G. H., \& Singh, I. (1999). Enterprise reform in China: Ownership, transition, and performance. Retrieved from https://bit.1y/2AMumPP (accessed on 15 July, 2009)

Ketsiri, K., \& Pajongwong, P. (2016). Knowledge and understanding of accountants toward rules for calculating net income for corporate income tax by section 65 ter in Thailand. International Journal of Business and Economic Affairs, 1(1), 67-73. doi:https://doi.org/10.24088/ijbea-2016-11009

Lee, E., Walker, M., \& Zeng, C. (2014). Do Chinese government subsidies affect firm value? Accounting, Organizations and Society, 39(3), 149-169. doi:https://doi.org/10.1016/j.aos.2014.02.002

Lewis, J. A. (2007). Building an information industry in China: National strategy and global markets. Washington, D.C., WA: Center for Strategic and International Studies.

Lu, J., \& Tao, Z. (2009). Trends and determinants of China's industrial agglomeration. Journal of Urban Economics, 65(2), 167-180. doi:https://doi.org/10.1016/j.jue.2008.10.003

Marquis, C., \& Qian, C. (2013). Corporate social responsibility reporting in China: Symbol or substance? Organization Science, 25(1), 127-148. doi:https://doi.org/10.1287/orsc.2013.0837

McNally, C. A. (2007). China's emerging industrial economy. New York, NY: Routledge.

Phyoe, E. E. (2015). The relationship between foreign direct investment and economic growth of selected ASEAN Countries. International Journal of Business and Administrative Studies, 1(4), 132-146. doi:https://doi.org/10.20469/ijbas.10002 $-4$

Qazi, A. Q., \& Yulin, Z. (2012). Productivity measurement of hi-tech industry of China malmquist productivity index-DEA approach. Procedia Economics and Finance, 1, 330-336. doi:https://doi.org/10.1016/s2212-5671(12)00038-x

Shah, A. (2006). Fiscal incentives for investment and innovation. Retrieved from https://bit.1y/2VMI0v4 (accessed 1 June, 2016)

United Nations Conference on Trade and Development. (1999). World investment report 1999. Retrieved from https:// bit.1y/2TUqS53 (accessed on 14 June, 2018)

Yoo, J., Lee, M. K., \& Lee, W. S. (2016). Asymmetrical corporate responses to economic information: Applying the firm size effect. Journal of Administrative and Business Studies, 2(1), 29-34. doi:https://doi.org/10.20474/jabs-2.1.4

Zhang, Q., Jiang, J., \& Feng, J. (2017). Influence of tax incentives on independent intellectual. American International Journal of Social Science, 6(8), 23-40. 